DOI 10.22460/infinity.v6i2.p149-156

\title{
EXPERIMENTATION OF SPICES LEARNING STRATEGIES WITH THE METHOD OF PROBLEM BASED LEARNING (PBL) TO BUILD MOTIVATION AND THE ABILITY TO THINK LOGICALLY FOR VOCATIONAL SCHOOL STUDENTS
}

\author{
Anggita Maharani $^{1}$, Laelasari ${ }^{2}$ \\ ${ }^{1,2}$ Swadaya Gunung Djati, Jl. Pemuda No.32, Sunyaragi, Kesambi Cirebon, West Java, Indonesia \\ 'anggi3007@yahoo.co.id, ${ }^{2}$ lala.mathunswagati@gmail.com
}

Received: November 11, 2016 ; Accepted: July 11, 2017

\begin{abstract}
This study aims to expose the interactions that occur in the process of mathematics learning and describe a method of learning motivation and logical mathematical thinking of students in classes. The method used in this research was a quasi-experimental design group post-test. In its implementation, this study uses a class experiment. Qualitative data are obtained in the form of motivational learning scale, whereas the quantitative data in the form of logical thinking ability score using normalized gain. The results showed the existence of a positive interaction during learning. However, learning motivation of students didn't show a significant improvement. While the logical thinking ability of students after learning of mathematics using the strategy of SPICES with PBL method is in the category is fair. In its implementation, the strategy of SPICES needed support some teachers from several fields of science.
\end{abstract}

Keywords: Logical Thinking, Problem Based Learning, SPICES, Motivation.

\begin{abstract}
Abstrak
Penelitian ini bertujuan untuk menelaah interaksi yang terjadi dalam proses pembelajaran matematika menggunakan strategi SPICES dengan metode $P B L$ dan mendeskripsikan motivasi belajar dan berpikir logis matematis siswa pada kelas yang menggunakan strategi SPICES dengan motode PBL. Metode yang digunakan dalam penelitian ini adalah kuasi eksperimen dengan disain kelompok postes. Dalam implementasinya, penelitian ini menggunakan satu kelas eksperimen. Data kualitatif yang diperoleh berupa skala motivasi belajar matematika siswa, sedangkan data kuantitatif berupa skor kemampuan berpikir logis dihitung gain ternormalisasinya. Hasil penelitian menunjukkan ad anya interaksi yang positif selama pembelajaran. Namun demikian, motivasi belajar siswa tidak mengalami peningkatan yang signifikan. Sedangkan kemampuan berpikir logis siswa setelah mendapat pembelajaran matematika menggunakan strategi SPICES dengan metode $P B L$ termasuk ke dalam kategori cukup. Dalam implementasinya, strategi SPICES memerlukan dukungan beberapa guru dari beberapa bidang ilmu.
\end{abstract}

Kata Kunci: Berpikir Logis, Problem Based Learning, SPICES, Motivasi.

How to Cite: Maharani, A., \& Laelasari (2017). Experimentation of Spices Learning Strategies with the Method of Problem Based Learning (PBL) to Build Motivation and the Ability to Think Logically for Vocational School Students. Infinity, 6 (2), 149-156. doi:10.22460/infinity.v6i2.p149-156 


\section{INTRODUCTION}

A graduate expected by the industry is to have basic mathematical skills with the ability of concept that can apply to practices and used in any workplace. However, corporate leaders often find that young people are unable to apply math concepts they have learned in school to the new problems in the workplace. Based on the analysis of the automotive business in West Java, the industry needs the level of intelligence, namely the ability to think logically, ability to solve problems, the ability to use logic techniques and reasoning techniques. Skills required by the industry are mathematical ability of students. But the survey results from several automotive business places (ATPM) conducted by researchers in the area of West Java, indicating that the test results of mathematics from VHS graduates were far from expected. From the results of the interviews with the teachers of the VHS, the main cause of the low ability of vocational students is the lack of motivation in learning, especially for math lessons.

It is necessary to use an effective learning method that capability for increase student learning motivation so that VHS students can be able to have the skills expected by the curriculum and industry like ability of logical thinking,creative ability, high work motivation, perseverance, and the disposition of mathematics. One of the ways to involve students actively in the learning process, student-centered, integrated, problem-based, community-based, elective and systematic study of the concept is to use SPICES. PBL uses the issue as a focal point for the purpose of investigation and research students. The essence of PBL involves the presentation of authentic situations and meaningful, which serves as the foundation for the investigation and the inquiry.

\section{SPICES Learning Strategies}

SPICES was born from the world of medical education. An article written by Dent (2014) writes that SPICES provides opportunities for student-centered, integrated learning and problem-solving. Some phenomena that occur in the learning process, has become the reason to change the paradigm of learning through various innovations. Orientation of learning goals is now not only for students to remember for the short term, but the results of the learning process should be able to equip students to solve problems in the long term.

In 1984, Harden et al. initiate the concept of SPICES. At first, this learning concept was practiced and developed in medical education. SPICES are an acronym for (1) Studentcentered, (2) Problem-based, (3) Integrated, (4) Community-based, (5) Elective, (6) Systematic. It illustrates learning components that are presented in the SPICES strategy.

1. Student-centered means learning is oriented on the student's activity. The student is a subject who actively learn to build his understanding through experience that has owned as well as the experience of the recently found. Student-centered learning can be done by students in confronts to the real world through learning resource that can encounter.

2. Problem-based. Learning starts with the actual problems and authentic, will give meaning to students. Through a problem, students will learn the concepts/theories at the same time solve the problem. Thus, learning not only produce (answer) but also generating process (how to solve the problem).

3. Integrated-based. An integrated approach based on the view that the learner or student builds their understanding of topics they have to learn rather than recording a lesson in the form is arranged systematically. Learning objectives on integrated learning is to help students achieve the learning objectives are interrelated. 
4. Community-based. SPICES learning strategy takes the problems that are happening in the community as the "starter" to obtain a meaningful learning. Learning with this strategy also invites students to be able to implement what he have learned into the context of a society.

5. Electives. Every student has diverse characteristics. Innovative learning should pay attention to the characteristic on each student. As a subject can determine when students want to learn and how to learn. The teacher acts as a source of learning, tutors, counselors, evaluators, and motivational speaker.

6. Systematic. The substance of the subject matter, generally the hierarchical. A material sometimes required other materials as prerequisites. Each procedural step is a prerequisite for the next step. Thus, the study should be done systematically.

Views of the components contained in the acronym SPICES, this strategy offers several advantages as a follow, (1) foster the student's motivation and activeness in his education, (2) develop the skills of solve the problems creatively and comprehensive, (3) develop analytical and logical thinking skills sharper and comprehensive, (4) build social skills, (5) provide opportunities for students to learn in accordance with his interest, (5) gives the feel of an orderly and effective learning.

\section{Problem Based Learning (PBL)}

PBL have the following characteristics: (1) learning begins with a problem, (2) ensures that problems are related to the real world of students, (3) organizes lessons around issues, not around disciplines, (4) give students full responsibility for experiencing their own learning process directly, (5) using small groups, and (6) demanding students to demonstrate what they have learned in the form of a product or performance.

Problem-based learning is a learning in the classroom to organize learning around problemsolving activities through the delivery of arguments and mathematical ideas, and communicating to peers through the interaction of various components in the classroom (Soekisno, 2015)

According to Forgarty (Rusman, 2010), problem-based learning starting with issues that are not structured (something that messed up). Five stages of PBL as follows:

1. Provide orientation about the issue to students

Based on its structure, problems in learning can be classified into two types, namely the problems defined clearly (well-defined) and the problems that are not clearly defined (illdefined). In PBL, students are given a structured problem ill-defined context of daily life.

2. Organizing students to do research

The results of the research on problem-solving that are practiced in class with something ill-defined structure problem, impacts as follows (1) discovery problem can increase creativity; (2) motivate students to make learning feels good; (3) problems with ill-defined structure requires skills different from standard-problem (4) encourage students to understand and acquire relations problems with specific disciplines (5) the information entered into the long-term memory is more amplified by using ill-defined structured problem (Krulik \& Rudnick, 1995). 
3. Helping independent investigation and groups

Students prepare temporary answers against the problems involving logic-mathematical intelligence. Students conduct an investigation of the data and information obtained is problems oriented.

4. Develop and present the results

Students revise the formulation of the problem through the real picture that they understand. Students involve verbal-linguistic intelligence fix the problem formulation statements wherever possible to use a more appropriate word. A reformulation of problems is a more focused investigation, and clearly shows the facts and information that need to be searched, as well as providing a clear objective in analyzing the data.

5. Analyze and evaluate the process of solving the problem

Learning assessment according to constructivist paradigm to be an integral part of learning itself. Starting from this view, the assessment of learning PBL implemented integrated with the learning process.

\section{SPICES Strategies using PBL in Learning Mathematics of VHS}

The principle of learning to do, learning to be, and learning together implies that mathematics learning should be based on the idea that learning should be comprehensive and integrated. The learning materials according to Dewey (FIP-UPI, 2007) should be prepared by considering two main requirements as follows:

1. Prepared concretely and in detail, been useful for life and truly is a necessary learning material.

2. The knowledge gained as a result of learning, is placed in a position that meaningful, which allows doing new activities is the development of previously acquired.

In order for the learning of mathematics VHS line with the needs, the context chosen is related to the field of vocational correspond to areas of expertise by way of design learning integrated material vocational through strategies to encourage students to actively search for information related to the context of everyday life.

\section{Motivation to Learn}

Motivation will arise if a person has a purpose to be an interest. By having a goal, someone will have the energy to achieve it. Sardiman (2012) says that motivation is the driving force that leads to learning activities. The characteristics of motivation according to Sardiman (2012) is (1) Persevering in the face of the task (work continuously for a long time); Resilient in the face of adversity (not easy to despair); (3) Does not need a push from the outside to perform as best as possible (not easily satisfied with the accomplishments that have been achieved); (4) Shows interest in all kinds of things; (5) Prefer to work alone; (6) Quickly bored against the routine tasks; and (7) Happy searching and solving problems.

The motivation of the students in the learning process will be very influential towards the achievement of learning objectives. As expressed by Elliott and Dweck (2005) that motivation is a very important factor affecting the learning and achievement of learning ranging from childhood to adolescence. The incidence of motivation, can be influenced by external factors (influence from outside) and internally (from within own influences). External influences such as praise teachers, get value or graduation, or desire to compete with his friend. While internal factors can be a form of interests, talents, or ideals. In line with 
that, Slavin (2008) also States that the motivation encourages students to do the learning activities.

It is very important to motivate students. Motivation as the process has some function especially in the achievement of learning objectives. The motivational function of Hamalik (2009) includes: (1) Encouraging the emergence of behavior or an act; (2) Motivation serves as directors; and (3) The motivation serves as a driving force.

The teacher has responsibility for creating a classroom environment that can foster the learning motivation of students. A variety of mathematical ability is expected to appear in accordance with the indicator NCTM, will not be achieved without the motivation of the student. In building conceptual understanding for example. Motivation to learn to be critical in the achievement of understanding in all areas. A study of motivation in students of VHS conducted by Bakar (2014) in the region of West Sumatra, indicating that there was significant influence between the motivation of learning with the competence of the productive.

\section{Logical Thinking Ability}

Think logically refers to understanding (understand), application capabilities, the ability of analysis, synthesis capability, even the ability to form evaluation skills (a process). Logical thinking can also be interpreted as measures. Logical thinking is an important basic skill of mathematics. Logical thinking is the key to drawing inferences and solve problems that are complex. Logical thinking is not the same as the logical reasoning, but both contain some similar activities. It is expressed by Sumarmo, Hidayat, Zukarnaen, Hamidah \& Sariningsih (2012) that in some discussion of the term logical thinking is often interchangeable with the term logical reasoning. Further, Sumarmo, et. all (2012) said that indeed, the term logical thinking has a wider coverage of logical reasoning.

In the process, logical thinking ability is measured based on the results of the Test of Logical Thinking (TOLT) which was initiated by Capie and Tobin (Sumarmo, et. All, 2012) is based on the theory of the mental development of Piaget. The question of the Test of Logical Thinking (TOLT) which includes five components: control variables (variable controlling), proportional reasoning (proportional reasoning), probabilistic reasoning, correlational reasoning, and combinatorial thinking. The question of the test consists of 10 item in the form of multiple choice with five answer choices are accompanied by a selection of the reason.

In addition to the Test of Logical Thinking (TOLT), there is also a Longeot test developed by the Sheehan (Sumarmo, et. All, 2012). Sheehan classifies mental development of the child into 26 rounds of test items which include formal logic components, a combination of formal, formal and proportions. In a test of Longeot, sublogic tests or formal reasoning proposition presented in the form of a series of statements, followed by a choice answers as logical conclusions based on inference rules. Further, reasoning that inference is called logical reasoning.

The operational definition of logical thinking that is used in this study is the definition of logical thinking as revealed by Sumarmo, et. all (2012) i.e.,

1. Draw conclusions or making the forecasts and interpretations based on the proportion of the corresponding 
2. Draw conclusions or making the forecasts and the predictions based on opportunities

3. Draw conclusions or make estimates and predictions based on the correlation of two variables

4. Set the combination of multiple variables

5. Analogy is drawing conclusions based on the likeness of the two processes

6. Do proofs

7. Arrange the analysis and synthesis of several cases

\section{METHOD}

This is quasi-experimental research with the pretest-postest design. In its implementation, this research uses experimental group i.e. one class with learning strategies using the SPICES with the methods of PBL. During the learning process, the motivation of student learning was observed. Implementation of the research consisted of two stages. The first stage is an introduction which consists of problem identification, preparation of instrument, and learning device with the development, continued with the test validation and reliability of learning device. Next is the determination of the control and experiments classes from school to be a place of experimentation. The next stage is the implementation of the research. Data collection is done by administering a test question the ability of logical thinking and observations about the motivation of learning that occurs during the learning process. The logical thinking ability tests had previously tested for the validity, reliability, power of distinction, and index of difficulty. Data processing is carried out to know the existence of a correlation between learning motivation caused from the use of the strategy of SPICES with PBL method against the logical mathematical thinking ability of students.

\section{RESULTS AND DISCUSSION}

Observations on student activities are conducted by the observer for each meeting. The format of the observation is filled with the aim to know the extent of student activity during the learning process takes place. Observations on student activities were conducted by three observers for each meeting. The focus of observation consists of 8 observed aspects. While the indicators were observed based on the learning steps by using SPICES strategy with PBL method.

Tabel 1. Recapitulation Results of Learning Activity

\begin{tabular}{ccc}
\hline Variable & Day & Average \\
\hline & 1 & 66,37 \\
Activity & 2 & 71,46 \\
& 3 & 75,88 \\
& 4 & 81,14 \\
\hline
\end{tabular}

The motivation analysis of students learning based on the results obtained after the student's mathematical learning experience using the strategy of SPICES with PBL method. The results are the following; there are increased on each of his encounters, though not too significant, the average learning motivation of students at the first meeting is 5.03 with percentage is $55.87 \%$ by category is enough, while the average of student learning motivation at the end of the meetings reached only $58.73 \%$ with category is enough. 
Tabel 2. Recapitulation Results of Learning Motivation

\begin{tabular}{ccccc}
\hline Variable & Week & Average & \% & Category \\
\hline \multirow{2}{*}{ Motivation } & 1 & 5,03 & 55,87 & Enough \\
& 4 & 5,28 & 58,73 & Enough \\
\hline
\end{tabular}

The average results of pre-test from the ability of logical thinking are 29,43 with the minimum value is 13 and the maximum value is 38 . While the average results of the post-test are 68.11 with a minimum value is 16 and a maximum is 85 . The results from the calculation of the correlation are 0.704 which means in the category of enough. By taking the real extent of $\alpha=5 \%, \mathrm{~N}=35$, and the value of $\mathrm{df}=(35-2)=33$ so retrieved 0.344 rtabel. Because the rser > rtabel that is $0.704>0.344$ then it can be inferred that there was a significant positive relationship between learning motivation caused from the use of the strategy of SPICES with PBL method against the logical mathematical thinking ability of students.

Tabel 3. Recapitulation Results of Logical Thinking Ability

\begin{tabular}{ccccc}
\hline Variable & Test & Average & Deviasi Standart & Varians \\
\hline \multirow{2}{*}{ Logical Thinking Ability } & Pretest & 29,43 & 7,322 & 53,605 \\
& Postest & 80,11 & 12,774 & 163,163 \\
\hline
\end{tabular}

\section{CONCLUSION}

The results showed the existence of a positive interaction during learning. Nevertheless, learning motivation of students did not experience a significant improvement. While logical thinking ability of students after learning of mathematics using the strategy of SPICES with PBL method is included in the category is enough. Nevertheless, we can say that the use of the strategy of the SPICES with the methods of PBL can grow learning motivation of students that is expected to give significant effects against mathematical ability improvement. In its implementation, the strategy of SPICES needed support some teachers from several fields of science. This is intended so that the given problem on students can be served authentically and integrative in accordance with characteristics of SPICES and PBL.

Application of SPICES strategy with PBL method of student-centered learning activities, so students participate in the learning process, learn how to develop independent and group learning, and discuss what they have thought and make students more active during the learning process. With the onset of student activeness, students can develop their potential. Activity of students in learning can stimulate and develop the talents they have, critical thinking, and can break the problems in everyday life. Stages in the SPICES strategy with PBL method in addition to increasing student activity, the stage can also increase students' learning motivation in the classroom. It can be seen from the result of observation analysis of students' learning motivation during the learning process by applying SPICES strategy with PBL method take place. The result of the observation analysis shows that the students' learning motivation has improved in every learning process. This shows that by applying SPICES strategy with PBL method in the classroom, it can grow student's learning motivation. The result of data analysis is known that there is significant influence on SPICES strategy implementation with PBL method to students' logical thinking ability. 


\section{REFERENCES}

Bakar, R. (2014). The Effect of Learning Motivation on Student's Productive Competencies in Vocational High School, West Sumatra. International Journal of Asian Social Science, 4(6), 722-732.

Dent, J. A. (2014). Using the SPICES Model to Develop Innovative Teaching Opportunities in Ambulatory Care Venues. Korean Journal of Medical Education, 26(1), 3-7.

FIP-UPI, T.P.I.P. (2007). Ilmu dan Aplikasi Pendidikan I: Ilmu Pendidikan Teoretis. PT Imperial Bhakti Utama.

Elliott, A.J., \& Dweck, C.S. (2005). Handbook of Competence and Motivation. New York: Guilford Press.

Hamalik, O. (2009). Metode Evaluasi dan Kesulitan-Kesulitan Belajar. Bandung: Tarsito.

Krulik, S., \& Rudnick, J. A. (1995). The New Sourcebook for Teaching Reasoning and Problem Solving in Elementary School. A Longwood Professional Book. Boston: Allyn \& Bacon.

Rusman (2010). Model-Model Pembelajaran Mengembangkan Profesionalisme Guru. Jakarta: Raja Grafindo Persada.

Sardiman, A.M. (2012). Interaksi dan Motivasi Belajar Mengajar. Jakarta: Rajawali Pers.

Slavin, R. E. (2008). Cooperative Learning, Success for all, and Evidence-Based Reform in Education. Éducation et didactique, 2(2), 149-157.

Soekisno, R. B. A. (2015). Pembelajaran Berbasis Masalah untuk Meningkatkan Kemampuan Argumentasi Matematis Mahasiswa. Infinity Journal, 4(2), 120-139.

Sumarmo, U., Hidayat, W., Zukarnaen, R., Hamidah, M., \& Sariningsih, R. (2012). Kemampuan dan Disposisi Berpikir Logis, Kritis, dan Kreatif Matematik (Eksperimen terhadap Siswa SMA Menggunakan Pembelajaran Berbasis Masalah dan Strategi ThinkTalk-Write). Jurnal Pengajaran MIPA, 17(1), 17-33. 